\title{
HAK DAN KEWAJIBAN WARGA NEGARA DALAM MENGIKUTI VAKSINASI COVID-19
}

\section{LEDISTA DEANUR}

IIK STRADA INDONESIA

\author{
ledistadeanur@gmail.com
}

\begin{abstract}
Abstrak
Pandemi Covid-19 menimbulkan status kedaruratan di Indonesia. Melalui keputusan Presiden Nomor 11 Tahun 2020, Indonesia telah mengumumkan status kedaruratan kesehatan. Berbagai upaya dilakukan dalam rangka mengatasi dampak pandemi Covid-19. Salah satunya adalah upaya vaksinasi. Namun, di masyarakat timbul pro kontra terkait vaksinasi tersebut. Sejumlah kalangan masyarakat menolak untuk divaksin. Oleh sebab itu, artikel ini akan menjelaskan apakah vaksinasi merupakan hak atau kewajiban bagi masyarakat. Hal ini menunjukkan bahwa vaksinasi yang pada mulanya adalah hak setiap orang, dapat menjadi suatu kewajiban mengingat situasi kedaruratan di Indonesia saat ini, karena seseorang yang tidak divaksin berpotensi untuk menularkan bahkan membunuh orang lain. Vaksinasi dalam rangka penanganan Covid-19 adalah suatu hak sekaligus kewajiban dari warga negara. Memang, terdapat hak seseorang untuk memilih pelayanan kesehatan baginya. Namun bisa dilihat pada konteks virus Covid-19 yang berskala pandemi, serta merujuk pada poin kedua bahwa seseorang yang tidak divaksin justru dapat berpotensi menjadi virus carrier bagi orang lain, maka hak tersebut dapat dikurangi dalam rangka untuk mencapai tujuan negara yakni melindungi segenap bangsa Indonesia dan seluruh tumpah darah Indonesia (dalam hal ini, melindungi dari virus Covid-19), dan juga termasuk melindugi hak asasi seseorang itu sendiri dalam rangka memperoleh hak untuk hidup secara sehat
\end{abstract}

\section{Kata kunci : vaksinasi, hak asasi, warga negara, tanggung jawab}

\section{Latar Belakang}

Sejak 2019 lalu, dunia diguncang oleh Pandemi COVID-19 yang bermula di Wuhan, Hubei, Republik Rakyat Tiongkok. Pandemi didefinisikan sebagai wabah penyakit menular berskala besar yang bisa meningkatkan morbiditas dan mortalitas suatu wilayah geografis yang luas dan menyebabkan permasalahan baik dari segi kesehatan, ekonomi, sosial, dan politik. Kini sudah tercatat 133 juta kasus terinfeksi COVID-19 di dunia dan 1.5 juta kasus di Indonesia. Kondisi pandemi telah mengakibatkan suatu krisis yang berdampak terhadap semua aspek kehidupan manusia. Meskipun sudah tersedia banyak obat dan metode penanganan pasien COVID-19, lonjakan kasus positif dan mortalitas masih tetap terjadi. Upaya pencegahan 3M (memakai masker, menjaga jarak, dan mencuci tangan) dinilai kurang cukup untuk menekan penyebaran virus ini sebab diperlukan sesuatu yang dapat menjaga kesehatan secara menyeluruh untuk mengurangi dampak 
sosial dan ekonomi masyarakat. Belum lagi ditambah dengan ketidakpatuhan warga terhadap penerapan protokol kesehatan. Selain karena kurangnya edukasi, ketidakpatuhan warga disebabkan oleh motif ekonomi, sikap tidak peduli, merasa berpotensi rendah terhadap penularan virus, serta ketidakpercayaan kepada pemerintah yang mengeluarkan kebijakan dan pernyataan yang inkonsisten. Hal ini seolah membantu membuat pandemi berlangsung lebih lama hingga saat ini.

Menurut data yang dirilis Gugus Tugas Percepatan Penanganan Covid-19 Republik Indonesia, jumlah kasus kematian karena Covid-19 di Indonesia adalah 33.183 orang. Dari angka ini dapat disimpulkan bahwa case vatality atau tingkat kematian yang disebabkan oleh Covid-19 adalah sekitar 2,7\%. Case vatality rate adalah presentase jumlah kematian dari seluruh jumlah kasus positif Covid-19 yang sudah terkonfirmasi dan dilaporkan. Dalam upaya mengembalikan kondisi dunia sebagaimana sebelum pandemi, telah diusung program vaksinasi oleh pemerintah di seluruh dunia, termasuk Indonesia. Vaksinasi COVID-19 telah mengalami perjalanan yang panjang untuk memastikan keamanan dan keampuhannya melalui berbagai penelitian dan uji coba. Program vaksinasi dianggap sebagai kunci dalam mengakhiri pandemi karena dapat digunakan dalam rangka mengurangi angka penyebaran virus serta membentuk kekebalan kelompok terhadap virus COVID-19. Namun, perjalanan vaksin hingga diterima dengan baik dan didistribusikan kepada masyarakat luas saat ini membutuhkan proses yang lebih panjang karena masih terdapat pro dan kontra terhadap vaksinasi.

Kesehatan adalah hak asasi setiap manusia, termasuk memperolah vaksin Covid-19. Hal ini dengan tegas telah dijamin oleh Undang-Undang Pasal 25 Universal Deklarations of Human Rights menetapkan bahwa "the enjoyment of the highest attainable standard of health is one of the fundamental rights of every human being)...". Selanjutnya dalam Pasal 28 Huruf H Undang-undang Dasar 1945 juga menegaskan bahwa setiap orang berhak hidup sejahtera lahir dan batin, bertempat tinggal, dan mendapatkan lingkungan hidup yang baik dan sehat serta berhak memperoleh kelayanan kesehatan. Lebih lanjut, Pasal 4 Undang-undang Nomer 36 Tahun 2009 tentang kesehatan juga menegaskan bahwa "setiap orang berhak atas kesehatan". Melihat beberapa aturan tersebut dapat diketahui bahwa memperoleh vaksin Covid-19 merupakan bagian dari hak untuk memperoleh kesehatan. Pemerintah bertanggung jawab merencanakan, mengatur, menyelenggarakan, membina, dan mengawasi penyelenggaraan upaya kesehatan yang merata dan terjangkau oleh masyarakat.

Sebaliknya, bahwa vaksinasi Covid-19 juga sekaligus kewajiban bagi warga negara Indonesia yang harus dilaksanakan. Sesuai ketentuan Pasal 9 Undang-undang nomor 36 Tahun 2009 tentang kesehatan ditentukan bahwa "setiap orang berkewajiban ikut mewujudkan, mempertahankan dan meningkatkan derajat kesehatan masyarakat yang setinggi-tingginya". Kewajiban ini meliputi upaya kesehatan perseorangan, upaya kesehatan masyarakat, dan pembangunan berwawasan kesehatan. Namun demikian dalam masyarakat terjadi pro dan kontra dalam pelaksanaan vaksin Covid-19. Banyak dari masyarakat yang tidak mempercayai penggunaan vaksin sebagai solusi dalam mengakhiri pandemi. Berdasarkan survei mengenai penerimaan vaksin COVID-19 yang dilakukan 
oleh Kementerian Kesehatan (Kemenkes) Republik Indonesia, Indonesia Technical Advisory Group on Immunization (ITAGI), United Nations Children`s Fund (UNICEF), dan World Health Organization (WHO) yang dilakukan pada September 2020 dan melibatkan 115.000 responden, mendapatkan hasil bahwa masih banyak masyarakat yang ragu bahkan menolak vaksinasi COVID-19, di mana sebanyak 7,6\% menolak dan 27\% ragu-ragu. Alasan dibalik penolakan dan keraguan mengenai vaksin tersebut sangatlah beragam, seperti tidak yakin terhadap keamanan vaksin, ragu terhadap efektivitas vaksin, takut terhadap efek samping vaksin, tidak mempercayai kegunaan vaksin, dan karena keyakinan agama. Ketidakpercayaan dan keraguan banyak masyarakat terhadap vaksin COVID-19 tak lepas dari banyaknya kesimpangsiuran informasi dan minimnya edukasi yang memadai. Padahal, akses informasi edukasi mengenai vaksinasi dalam pandemi dapat meningkatkan kepercayaan masyarakat terhadap vaksinasi, sehingga dapat membantu proses vaksinasi oleh pemerintah.

\section{Kasus/Masalah}

Dalam upaya mengembalikan kondisi dunia sebagaimana sebelum pandemi, telah diusung program vaksinasi oleh pemerintah di seluruh dunia, termasuk Indonesia. Meski terdapat pro dan kontra di masyarakat tetapi vaksin Covid-19 merupakan salah satu cara untuk menekan angka kasus positif Covid-19. Pada kasus ini identifikasi masalah yaitu "apakah vaksin Covid-19 merupakan Hak atau Kewajiban setiap warga negara Indonesia?"

\section{Tinjauan Pustaka}

\section{Hak dan Kewajiban Vaksinasi}

Pandemi Covid-19 menjadi permasalahan yang dialami hampir di semua Negara, tidak terkecuali Indonesia. Atas dasar hal tersebut Indonesia memiliki tanggung jawab dalam hal menanggungi dengan berbagai upaya dan kebijakan yang dikeluarkan. Peter Salim mengungkapkan bahwa terminologi tanggung jawab dalam khazanah ilmu hukum ada tiga hal yakni, liability, responsibility, dan accountabilit,. Pertama, liability yang merupakan pertanggung jawaban hukum yang biasanya diwujudkan dalam bentuk tanggung jawab keperdataan. Kedua, responsibility yang berasal dari kata "response" yang berarti tindakan untuk merespon suatu masalah atau isu, dan ability yang berarti kemampuan atau dengan kata lain "ikut memikul beban”. Ketiga, accountability yang sering dikaitkan dengan masalah keuangan atau terkait masalah suatu kepercayaan terhadap lembaga tertentu yang berkaitan dengan keuangan. Tanggung jawab dalam konteks artikel ini terkait dengan tanggung jawab yang ketiga yakni responsibility dalam kaitannya pandemi dan pemenuhan vaksin Covid-19. Pemenuhan vaksin Covid-19 menjadi tanggung jawab penuh pemerintah sebagaimana bentuk mewujudkan tujuan Negara sebagaimana yang dapat kita lihat dalam alinea keempat Pembukaan UUD NRI Tahun 1945 yaitu melindungi segenap bangsa Indonesia dan seluruh tumpah darah Indonesia, memajukan kesejahteraan umum, mencerdaskan kehidupan bangsa, dan ikut melaksanakan ketertiban dunia yang berdasarkan kemerdekaan, perdamaian abadi dan 
Gejala klinis dari corona virus atau Covid-19 ini adalah demam, batuk, pilek, gangguan pernafasan, sakit tenggorokan, letih, lesu, gejala ini bisa berupa gejala ringan, sedang sampai berat tergantung imunitas tubuh penderita dan besar paparan virus covid19. Penularan penyakit ini melalui droplet (percikan cairan atau liur) dari hidung atau mulut penderita saat batuk atau bersin. Droplet tersebut terhirup oleh orang sehat atau droplet jatuh pada benda sekitar dan tersentuh orang sehat kemudian menyentuh mata, hidung dan mulut. Penularan Covid-19 sangat mudah tetapi pencegahannya pun mudah dengan 5M Plus yaitu memakai masker, sering mencuci tangan dengan sabun di air mengalir, menjaga jarak, mengurangi mobilitas dan menghindari kerumunan serta plus meningkatkan imunitas dengan olah raga rutin, konsumsi gizi seimbang serta berperilaku hidup bersih sehat. Jumlah kasus Covid-19 di Indonesia per tanggal 10 Februari 2021 terkonfirmasi mnecapai 1.174 .779 dengan penambahan kasus positif dalam 24 jam terakhir mencapai 8.700 orang. Berbagai upaya untuk menghentikan laju penambahan kasus diperlukan baik dari sisi pemerintah maupun dari masyarakat itu sendiri. Pemerintah telah mencanangkan 5M agar dilaksanakan oleh masyarakat, yakni Memakai masker, Mencuci tangan, Menjaga jarak, Menjauhi kerumunan, dan Mengurangi mobilitas. Pencegahan melalui 5M yang dicanangkan untuk menghentikan peningkatan kasus Covid19, ternyata belum mampu menghentikan perjalanan kasus Covid-19 di Indonesia.

Guna mempercepat upaya penanggulangan Covid-19 di Indonesia, pemerintah mencanangkan program pemberian vaksinasi Covid-19 kepada seluruh rakyat Indonesia. Sebanyak 3 juta vaksin Covid-19 yang diproduksi oleh Sinovac yang merupakan produsen vaksin Covid-19 telah didatangkan pemerintah Indonesia dalam dua tahap pada periode I.

a. Periode I (Januari-April 2021)

Tahap I, sebanyak 1,3 juta untuk tenaga kesehatan; tahap II, sebanyak 17,4 juta untuk petugas publik yang tidak dapat menerapkan jaga jarak secara efektif dan sebanyak 21,5 juta umtuk lansia (di atas umur 60 tahun)

b. Periode II (April 2021-Maret 2021)

Tahap III sebanyak 63,9 juta untuk masyarakat dengan resiko penularan tinggi, baik dari segi tempat tinggal atau kelas ekonomi dan sosial. Tahap IV, sebanyak 77,4 juta kepada masyarakat umum dengan pendekatan kluster sesuai ketersediaan vaksin.

Pelaksanaan vaksinasi Covid-19 di Indonesia banyak mengalami kendala di masyarakat. Sebagian masyarakat mendukung program vaksinasi Covid-19 ini, namun tidak sedikit yang meragukan efektifitas dan keampuhan vaksin Covid-19. Yang meragukan keefektifan dan keampuhan vaksin Covid-19. Beberapa di antaranya bahkan menolak untuk diberi vaksin. Vaksin Sinovac yang digunakan untuk vaksinasi Covid-19 telah di lakukan uji klinis dengan beberapa tahapan dan mendapat izin edar dari Badan Pengawasan Obat dan Makanan (BPOM) juga dari Majelis Ulama Indonesia (MUI). Meskipun demikian, masih terdapat beberapa argumen dari mereka yang menolak untuk divaksin Covid-19. Mereka yang menolak tidak sedikit yang berpendidikan tinggi dan bahkan dari kalangan kesehatan itu sendiri. Semoga saja argumen yang mereka sampaikan 
tidak menjadi sebuah provokasi yang akan mempengaruhi pikiran mereka yang sebenarnya mau divaksin. Guna menekan angka penularan Covid-19 di Indonesia, maka perlu dilakukan sosialisasi yang lebih intens di berbagai media, terutama media daring (online) akan manfaat dilakukannya vaksinasi Covid-19, yakni menuju "Kekebalan komunitas untuk menghentikan pandemi Covid-19”, dengan syarat minimal 70\% penduduk sudah mendapatkan vaksin.

Namum, diluar program vaksinasi yang memang terus dimatangkan pemerintah, masyarakat baik yang "mendukung, maupun yang" menolak" untuk diberi vaksin, harus tetap patuh menjalankan protokol kesehatan 5M. Protokol kesehatan tetap menjadi senjata paling ampuh dalam menekan penularan Covid-19, bahkan apabila vaksinasi sudah diterima oleh semua penduduk. Di indonesia kondisi Covid-19 sampai saat ini masih Fluktuatif, walaupun sudah cenderung mengalami penurunan. Upaya yang dilakukan pemerintah untuk mencegah, mengendalikan dan memutus mata rantai Covid-19 salah satunya adalah dengan program vaksinasi.

\section{Apa dan mengapa Vaksinasi?}

Vaksin adalah Produk atau zat yang dimasukkan ke dalam tubuh manusia yang akan menstimulasi sistem kekebalan (imun) tubuh manusia. Vaksinasi adalah prosedur untuk memasukkan vaksin kedalam tubuh utnuk menstimulasi sisitem imun tubuh agar dapat memproduksi imunitas terhadap suatu penyakit. Imunisasi adalah proses yang membuat tubuh manusia terlindung dari suatu penyakit melalui proses vaksinasi.Imunitas adalah kemampuan kekebalan tubuh melawan suatu penyakit.

\section{Mengapa perlu vaksinasi Covid-19?}

Vaksinasi Covid-19 diberikan agar tubuh mengenali virus tersebut dan memproduksi serta merangsang terbentuknya kekebalan tubuh sehingga mampu melawan virus di dalam tubuh. Dengan vaksinasi harapannya dapat menurunkan kasus konfirmasi, menjaga produktivitas masyarakat, melindungi kesehatan masyarakat serta mendorong terbentuknya kekebalan kelompok. Untuk terbentuknya kekebalan kelompok minimal $70 \%$ penduduk tervaksinasi. Vaksin covid yang digunakan sudah melalui uji pra klinik maupun klinik oleh BPOM sehingga dijamin mutu dan keamanannya.

\section{Pembahasan}

Kesehatan adalah keadaan sehat, baik secara fisik, mental, spiritual maupun sosial yang memungkinkan setiap orang untuk hidup produktif secara sosial dan ekonomis. Karena itu, kesehatan merupakan dasar dari diakuinya derajat kemanusiaan. Tanpa kesehatan, seseorang menjadi tidak sederajat secara kondisional. Tanpa kesehatan, seseorang tidak akan mampu memperoleh hak-hak lainnya. Sehingga kesehatan menjadi salah satu ukuran selain tingkat pendidikan dan ekonomi, yang menentukan mutu dari sumber daya manusia.

Berkaitan dengan penanganan pandemi Covid-19 di Indonesia, Pemerintah telah mengambil langkah-langkah dalam rangka melindungi kesehatan warga negara. Mulai dari 
menetapkan status darurat kesehatan melalui keputusan Presiden Nomor 11 Tahun 2020 tentang Penetapan Kedaruratan Kesehatan Masyarakat Corona Virus Disease 2019 (Covid-19), melaksanakan kewajiban Pemerintah dalam rangka melaksanakan 3T (testing, tracing, treatment). Pelaksanaan vaksinasi Covid-19 di Indonesia banyak mengalami kendala di masyarakat. Sebagian masyarakat mendukung program vaksinasi Covid-19 ini, namun tidak sedikit yang meragukan efektifitas dan keampuhan vaksin Covid-19, maka dari hal tersebut munculah pro dan kontra terkait pelaksanaan vaksinasi di Indonesia. Salah satu isu hukum berkaitan dengan vaksinasi ini merupakan hak ataukah kewajiban. Sebagaimana yang disebutkan pada bagian pendahuluan bahwa sejumlah aktivis tegas menyatakan bahwa menolak vaksin adalah hak asasi rakyat. Mereka menggunakan dasar hukum Pasal 5 ayat (3) Undang-Undang Nomor 36 Tahun 2009 tentang Kesehatan yang menyatakan bahwa "Setiap orang berhak secara mandiri dan bertanggung jawab menentukan sendiri pelayanan kesehatan yang diperlukan bagi dirinya." Dari hal tersebut menurut pendapat penulis vaksinasi Covid-19 merupakan salah satu solusi yang tentunya bisa diterima oleh masyarakat luas. Meski tak sedikit masyarakat yang menolak untuk melakukan vaksin tetapi ini merupakan langkah pemerintah yang tepat terkait hak dan kewajiban setiap masyarakat.

\section{Kesimpulan}

Vaksinasi dalam rangka penanganan Covid-19 adalah suatu hak sekaligus kewajiban dari warga negara. Memang, terdapat hak seseorang untuk memilih pelayanan kesehatan baginya. Namun bisa dilihat pada konteks virus Covid-19 yang berskala pandemi, serta merujuk pada poin kedua bahwa seseorang yang tidak divaksin justru dapat berpotensi menjadi virus carrier bagi orang lain, maka hak tersebut dapat dikurangi dalam rangka untuk mencapai tujuan negara yakni melindungi segenap bangsa Indonesia dan seluruh tumpah darah Indonesia (dalam hal ini, melindungi dari virus Covid-19), dan juga termasuk melindugi hak asasi seseorang itu sendiri dalam rangka memperoleh hak untuk hidup secara sehat. Oleh sebab itu, vaksinasi yang pada mulanya dalah suatu hak bagi seseorang dapat berubah menjadi suatu kewajiban mengingat negara dalam keadaan darurat dan selanjutnya akan berkaitan dengan kewajiban asasi manusia untuk menghargai hak asasi orang lain, dalam hak ini adalah hak atas kesehatan orang lain.

\section{Daftar Pustaka}

http://repositori.usu.ac.id/bitstream/handle/123456789/30025/170200565.pdf?sequence=1 \&isAllowed $=\mathrm{y}$

https://www.kompas.com/skola/read/2020/08/12/081500069/bagaimana-caramumenanamkan-sifat-antikorupsi-di-kehidupan-sehari-hari

https://bemfkunud.com/2021/04/28/vaksinasi-covid-19-solusi-menghadapi-pandemi/

https://www.litbang.kemkes.go.id/tantangan-pelaksanaan-vaksinasi-covid-19-diindonesia/ 
https://dinkes.bulelengkab.go.id/informasi/detail/artikel/49-efektivitas-vaksinasi-dalampemutusan-rantai-penularan-covid-19

Gandryani, F., \& Hadi, F. (2021). PELAKSANAAN VAKSINASI COVID-19 DI INDONESIA: HAK ATAU KEWAJIBAN WARGA NEGARA. Jurnal Rechts Vinding: Media Pembinaan Hukum Nasional, 10(1), 23.

Sodik, M. A., \& Akoit, A. (2016). Looks Personal Hygiene Of Student Senior High Scholl With The Herpes Disease.Journal of Global Research in Public Health,1(1), 73-78.

Sodik, M. A., \& Saheri, M. (2019). Corelation Study Between Knowledge, Attitude Toward Tenaager's Sexual Beahaviour Who Was Domiciled In English Village.Journal of Global Research in Public Health,4(2).

TAHIN, M. W., \& Sodik, M. A. (2021). Pengaruh Merokok Bagi Remaja Terhadap Perilaku dan Pergaulan Sehari-hari.

Attoriq, S., \& Sodik, M. A. (2018). Pencegahan Dan Pengendalian Infeksi Terkait Pelayanan Kesehatan Di Lahan Praktik.

TAHIN, M. W., \& Sodik, M. A. (2021). Pengaruh Merokok Bagi Remaja Terhadap Perilaku dan Pergaulan Sehari-hari.

Sodik, M. A., Suprapto, S. I., \& Pangesti, D. (2013). Faktor-Faktor Yang Berhubungan Dengan Pelaksanaan Pelayanan Prima Pegawai Di Rsui Orpeha Tulungagung.STRADA Jurnal Ilmiah Kesehatan,2(1), 24-32.

Tule, A. R., Siyoto, S., Dwianggimawati, M. S., \& Sodik, M. A. (2018). The Analysis Factors Affecting Interest In Medication Of Receipt Help Aid Bpjs Participant In Balowerti Public Health Center Kediri City.Journal of Global Research in Public Health,3(1), 68-75.

Oktoriani, E. N., Sutrisno, J., Mayasari, E., \& Sodik, M. A. (2018). Analysis of medical record complete flexibility to complete claims of health BPJS RS Baptis Kota Batu.Journal of Global Research in Public Health,3(1), 46-53.

Sodik, M. A., Astikasari, N. D., Fazrin, I., Chusnatayaini, A., \& Peristiowati, Y. (2018). Dental health child with retardation mental and parents behavior.Indian Journal of Physiotherapy and Occupational Therapy-An International Journal,12(4), 278-282. 